\title{
The Development of Accommodations around the Lake Balaton from the XVIII Century to the II World War
}

\author{
Endre György Bártfai ${ }^{1} \&$ Lili Bártfai ${ }^{2}$ \\ ${ }^{1}$ College of Commerce, Catering and Tourism, Budapest Business School, Budapest, Hungary \\ ${ }^{2}$ Royal Automobile Club, Hotel London, London, UK \\ Correspondence: Endre György Bártfai, Lecturer, College of Commerce, Catering and Tourism, Budapest Business \\ School, Budapest, Buzogány u., 1149 Hungary. E-mail: Bartfai.Endre@kvifk.bgf.hu
}

Received: April 25, 2015

Accepted: May 13, 2015

Online Published: May 17, 2015

doi:10.5430/jms.v6n2p93

URL: http://dx.doi.org/10.5430/jms.v6n2p93

\begin{abstract}
The study presents the history of accommodations around the Lake Balaton from the XVIII century to the II World War. After a brief description of the geology of the Lake Balaton, the writers investigate the development of the aquatic, rail and road transport; and their impact on the lake's tourism, and divided into three sections, provides an overview of the development of lodging of this nearly two-hundred-year period.

Keywords: Hungary - Lake Balaton it's sights and role in the Hungarian tourism, development of the traffic infrastructure, accommodation development, capacities and places, the first two hundred year from the XVIII century, types of the accommodations facilities
\end{abstract}

\section{Introduction}

... this is the kindest, most gentle and peaceful region on the Earth, indeed destined to be the relaxing resort in our overpopulated Earth" - JENÖ CHOLNOKY writes about Hungary in the introduction of his book The Geography of Hungary $(1929$, p. 6.).

Most foreign guests visiting our country recognize our two main tourist attractions: Budapest and the Lake Balaton. Today's key tourism status of the Lake Balaton is a result of a process spanning over centuries; it is worth exploring and knowing its origins.

The Lake Balaton region, the second most attractive tourism region after Budapest, has achieved increasing turnover data. The number of nights spent in the January - October 2014 period has decreased by $0.6 \%$ at foreign visitors; however it has increased by $4.6 \%$ at domestic visitors, compared to the same period of the previous year. The number of the foreign guest nights were 1709 thousand, and domestic guest nights were 2846 thousand in the first ten month (HSCO Quick Reference 2014. No.: 158.)

According to the study about the Lake Balaton's Regional Development Concept: The Balaton region is the second most important tourism region in Hungary - $22 \%$ of domestic tourism revenue is generated in this tourism region. In turn, examining the domestic tourism only, the Balaton region is the most significant receiving area in Hungary, considering visitors $(22.3 \%)$ and guest nights $(25.6 \%)$ as well.

The main features of the Balaton today are very similar to the old times:

- Short season (6-8 weeks) - lakeside bathing-based tourism.

- The absence of a large-scale development of the attractions, scattered developments.

- Weak marketing, isolated appearance of tourism services on the market, despite the international tourism trends services and experiences are not unified into packages.

- There is not an integrated, up-to-date information data base.

- Human resource available is not appropriate in all aspects (Balaton Concept until 20202009 pp. 48-49).

The aim of the study is to present the history of the hospitality industry of the lake-side towns and villages; its development and characteristics from the second half of the $18^{\text {th }}$ century to the Second World War; also how the "Hungarian Sea" has become the second most important tourism destination in Hungary and why more than half of the country's Hotels are located here. In addition, unconcealed aim is that the study serves as a source for other researchers about the coastal settlements lodgings, and their recognized capacity data. 


\subsection{Research Methods}

Our research method basically was a library research; books, period newspapers, magazines (Hungarian Baths and Tourism, Hungarian Hoteliers and Restaurateurs) from the National Széchenyi Library, the Library of the HSCO (Hungarian Central Statistical Office) and the Library of the Budapest Business School have provided the data. Special thanks to the head-librarians of the HCSO and the BBS to provide us access to their relics at their Special Collection.

\section{Results}

\subsection{Short, Tourism-Oriented Description of the Lake Balaton}

The regions and characteristics of the Lake Balaton, which are vital from a tourism point of view, will be presented based on Jenő Cholnoky's books “The Geography of Hungary (1929, 2010).

The Lake Balaton was created by trench subsiding, its average depth is only 3 metres, the deepest point is 11.5 meter at the Tihany Peninsula. The deepest parts of its two basins - East and West - are 4-5 metres deep. A 2-2.5 km long abrasion cliff edge accompanies the south coast, which is approximately seventy km long. The water there is very shallow, its soil is Pannonian sand, which makes this coast ideal for designing of beaches. The Sió-duct is to drain the excess water. The water of the Lake Balaton is fed by the Zala River, but the streams of the Balaton Highland also bring water. The water of the Balaton is weak mineral water, which is especially rich in sulphuric salts of alkaline earth metals. The water's colour is always greenish and blurred. A lot of fish live in the Lake Balaton, the most famous is a big bass called "fogas" (Lucioperca lucioperca L.) and the bream. The temperature of the water is changing rapidly with the air temperature. In the wintertime, due to the persistent cold, it freezes. "In the summertime the temperature of the water on the surface can reach up to 24 degrees, therefore it is very pleasant for swimming. Its water is also drinkable, which makes it much nicer than the seas." (J Cholnoky, 1929. p. 68.). In the winter the frozen lake not only offers great scenery, it is also suitable for winter sports e.g. ice-skating or ice-sailing. At the time when the ice melts, small cracks appear with big "bangs", they break out due to the high tension; locals call the "túrolás" (kind of mole-hill). At these locations open water arises, the process is called by residents "rianás". In the springtime, wind from the north creates big ice blockages on the south coast. On the south shore of the Lake Balaton, the former deflationary plain extends into the mounds of Somogy in deep bays, which due to the sand became moorland. The locals call these marshes the "berek". The biggest one is the Nagy-Berek (Big-Marsh) between Fonyód and Balatonkeresztúr.

The south slope of the Balaton Highlands, which is the southern part of the Bakony Hills, has been washed by the waves of the Pannon Sea, thus an abrasion terrace was created. "On the north shore of the lake, this beautiful 2-2.5 $\mathrm{km}$ wide gentle slope between the lake and the hills is called the Balaton Riviera. We can find the most charming baths and resorts, such as Almádi, Alsóörs, Lovas, Paloznak, Köves, Csopak, Arács, Balatonfüred, Aszófö, Örvényes, Akali-Dörgicse, Zánka, Szepezd, Révfülöp, and Ábrahám. On this slope excellent wine grows, and between the vineyards densely scattered wine cellars and weekend homes raise this region of Hungary to one of the most attractive and dear." (J Cholnoky 1929 p 54)

TheTapolcai-basin has deeply sunk into the western part of the Balaton Highlands, between two north-south directon fractures. The Pannon Sea has filled it up with sand and clay layers, on top of these layers bazaltic layers broke up during the Pliocene era. The basalt cover often has a very nice columnal separation, like in the north side of the Szent György Hill. Such beautiful basaltic hills are the Badacsony, the Szentgyörgy, the Haláp, the Csobánc, the Somlyó and the Sághegy. After the eruption of the basalt lava the location eroded, and when the erosion was very big, the mud volcanoes and steam bursts erupted. The sludge of the mud volcanoes created the Szigligeti-Hegy, the Vendég-hegy, the Kis-Hegyestő, the boglári Várhegy and the Tihanyi Hegyek. The Tapolca-basin divides the Balaton Highlands from the Keszthely Hills; the southern part of this latter is made of dolomite, and there are basalt-spills on the northern part (Láz Hegy, Szebike, Sarvaly, Tátika and the Kovácsi Hegy). These are beautiful examples for the lava-covered mesas. The castle crowned Sümegi Hill is the northernmost of all.

Jenö Cholnoky - realising the importance of the lake from a tourism point of view - write the followings about the Balaton: "Nowadays the importance of the lake is that as a resort it attracts a lot of foreigners. The most important resorts on the northern shore are Almádi, Szepezd, Révfülöp, Badacsony and Balatongyörök and Keszthely at the western end. On the south side there are Balatonberény, Balatonfenyves, Fonyód, Lelle, Boglár, Szárszó, Szemes, Földvár, Zamárdi, Siófok and Világos. On the north-eastern escarpment the most important resorts are Aliga, Akarattya, Kenese and Füzfö. There are a lots of visitors in Tihany as well.Those people, who desire to get better, are attracted to the lake by the carbonated (sour) water of Balatonfüred, and the thermal hot springs of Héviz. The 
carbonated waters popping up from below the Csopak, Füred and the bath resort, and the hot springs of Tapolca and Héviz are post-volcanic phenomena. "(Cholnoky J. 2010, pp. 273-274.)

When describing the geography of the Lake Balaton, we cannot forget about the Hévíz Lake. According to Sági's description (1902), Keszthely's great attraction is the sulphuric hot springs of the Hévíz Lake. Patients talk of miracles of the healing power of its water. The temperature of the water during the summer is 33-36 degrees, and it does not drop below 23 degrees in the wintertime either. Hévíz, as a thermal spring is unique with its plentiful water content, as a result 26 thousand hectolitres of water per day is flowing into the Kis Balaton through a channel. The attraction of Hévíz is the lotus flower, which was localized by Doctor Sándor Lovassy; this is the only place in Europe where this flower grows freely. According to the analysis of Dr Florian Heller in the book Bolemann (1900) the Hévíz Lake belongs to the warm akratic-thermas, additionally with a meter deep mud at the bottom. The thermal bath has a healing effect against arthritis, gout, number of skin diseases ulcers and nervous pains.

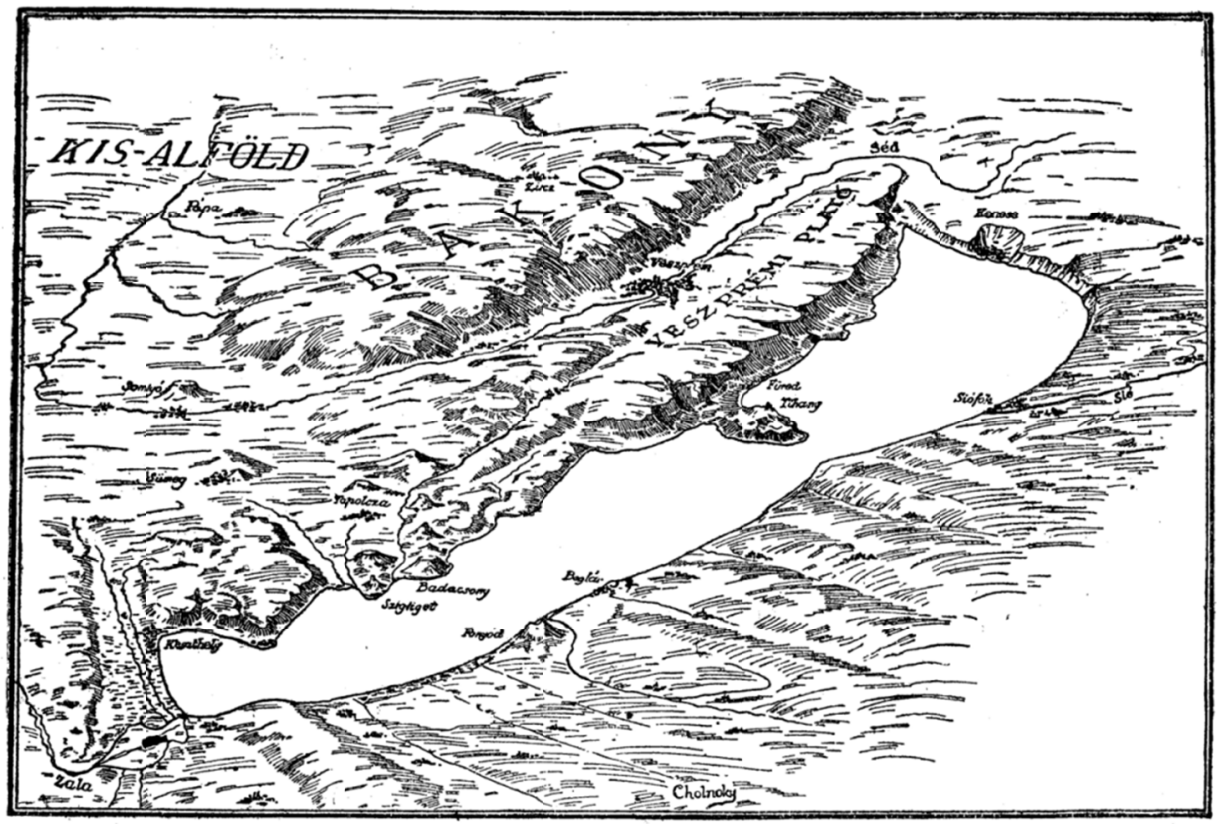

Figure 1. Bird's eye view picture the outskirts of the Lake Balaton

Source: Cholnoky J. 1929: Geography of Hungary p. 64.

\subsection{The Development of the Transport at Lake Balaton, and Its Effects on the Tourism}

The accessibility, easy availability played an important part that the Lake Balaton is considered as a tourism destination from the second half of the 19th century. It is worth briefly looking at the role of the shipping, rail and road transport.

\subsubsection{Brief History of the Shipping}

Before 1846, shipping on the Lake Balaton meant a few sailboats, vessels and three ferry crossings (between Fenékpuszta and Balatonszentgyörgy, Boglár and Fülöp, and Öszöd and Akali). The major breakthrough was the establishment of the Balaton Steamship Company by István Széchenyi and the construction of the Kisfaludy steamship. At this time shipping really only meant as local transport and economic aims, tourism has not yet been an aspect. In this era tourism mainly concentrated in Balatonfüred. Steamship carried the visitors from Keszthely, Kenese and Alsóörs to the resort on the north shore. After the Freedom War in 1848-49, regular passenger traffic could only restart after 1852 .

The construction and opening of the Southern Railway brought the Balaton closer to the world. After 1863, Kisfaludy gradually ceased its other routes, and only travelled between Siófok and Balatonfüred. The visitors travelling by rail to Siófok, and then to Balatonfüred quickly recognized the benefits of the Sió coastal town, and many rather stayed there than travelled on. This started the development of Siófok. From 1861 a sailing ferry was in 
operation on the Révfülöp-Boglár route, and from 1872 the steamship named Balaton, owned by the Zala-Somogy County travelled. The first screw-steamboat of the Lake did the Révfülöp-Boglár-Szepezd route. When the company, which was founded by Széchenyi, went bankrupt in 1876, the scheduled routes have been cancelled, which brought a decline to the Balaton, that particularly struck Balatonfüred and the Tihany Abbey.

Both the members of the Stefánia Yacht Association and the Southern Railway Company had interests in the re-opening of steam-shipping. Therefore on 21 October 1888 the Lake Balaton Steamship Company was founded to conduct the regular passenger and freight shipping. Mr Gábor Baross minister of transport financially supported the restart - although with strict conditions. On 1 July 1889 the new paddle boat - the Kelen, later re-named Baross ordered by the company began its scheduled routes between Almádi-Füred-Siófok-Füred-Almádi. In 1891, two new screw-steamships, the Kelen and the Helka were out in circulation. Around this time the shipping on the Lake Balaton began to develop rapidly, the former timer posts have been replace by stone piers, and steam-ships departed three times a day from some ports. In 1927 a new shipping company appeared on the Lake - the Balaton Shipping Company Ltd. In 1929 the first engine-powered ferry began its scheduled routes between Szántód and Tihany, replacing the former sailing ferry. This ship could carry 10 vehicles and 60 people at the same time and made the journey in 15 minutes. In order to raise the standard of travel, the company ordered four new ships. The Csobánc and Szigliget luxury engine-ships were introduced on the Balaton in 1927. To the passenger's convenience, two salons and two buffet-booths have also been developed on these ships. The Csongor and the Tünde engine-ships were also completed this year in Balatonfüred, in the shipbuilding plant of the IBUSZ. Two years later the motor boat named Sió was put in service on the lake as well - this ship was primarily an excursion ship and was capable of carrying 50 people. In 1935 the steady increase in the number of visitors on the Balaton justified the construction of the Boglár, and a year later the Badacsony was launched, which was capable of carrying 30 people. In 1938, two more ships were added to the Lake's fleet, the engine ships Szent István and Szent Miklós that were mainly used as ferry and excursion boats, and can be regarded as ancestors of the water-buses. As the heralds of the future the hydroplanes appeared at the end on the 1930's.

\subsubsection{Brief History of Rail Transportation}

In the first half of the $19^{\text {th }}$ century one of the main obstacles of the development in Hungary was the inadequate transport. Transportation of goods was by cart, while as public transport people used the stagecoaches. The appearance and spreading of the steam machines gave a great boost to the development of the transport in our country as well. As a result, in 1847 the Kisfaludy steam ship commenced its operation between Kenese-Füred-Keszthely, which was joined by the stagecoach route from Buda to Kenese. The plan was developed to build the Budapest-Nagykanizsa railway route, which was scheduled to pass through the southern coast of the Lake Balaton. In 1861 the South Railway Company handed over the new line, providing a great advantage for the settlements on the southern coast. There were many attempts to build the railway track on the north side - but all of them failed. In the early 1870's the Veszprém-Szombathely-Graz line of the Hungarian Western Railway was completed, part of this plan was to connect the Veszprém-Keszthely route with the new route. But it could not be implemented due to insufficient funds. In the following years a couple of smaller lines were opened, such as the Balatonszentgyörgy-Keszthely in 1883; the Boba-Sümeg in 1889, its continuation until Tapolca in 1891 and the Keszthely-Tapolca route in 1893. In the year of the Hungarian Milleneum (1896) the Danubian suburban railway's Veszprém-Dombóvár route was completed. By the turn of the $19^{\text {th }}-20^{\text {th }}$ century there were railway tracks almost everywhere around the Lake, except for the Akarattya-Szigliget section. SÁGI (1902) in his book mentions about the lack of the rail on the northern shore of the Balaton; and that the future of these villages and towns largely depend on the construction of railway lines. In the meantime the Balaton Association was established, that tried to take care of the railway-situation. In their organization a 3600 people delegation visited the Ministers of Agriculture and Trade on 22 July 1906, highlighting issue of railway around the Lake Balaton in the government's attention. The residents of the northern coastal settlements started to act, and 85000 korona (former Hungarian currency) were collected as a contribution to the development of the railway. The residents of Balatonfüred made a contribution of 40000 korona out of all. As a result, a new plan was outlined: starting from Pusztaszabolcs station, the rail was supposed to reach the Lake Balaton via Börgönd, Szabadbattyán and Polgárdi villages. In effect of this, Ferenc Kossuth decided to create and build the north-Balaton railway line. On 14 February 1907, the law on the construction has been announced, and early November the works had started on the Börgönd-Tapolca route. The $117 \mathrm{~km}$ long main line between Börgönd and Tapolca, and the $16 \mathrm{~km}$ long sub-line between Veszprém and Alsóörs was built in just over than a year and a half. On 1 July 1909 the railway route was opened on the north shore of the Lake, passengers could get from Budapest East Railway Station to Tapolca station in 5 hours. In 1912 there was a direct service from Vienna to Balatonfüred via Györ. (M Fazekas, 2005) 
Due to the lack of resources and space, single rail lines were established on the two banks of the Lake Balaton, therefore trains could only pass or take over one and another on the main stations. This is not exactly ideal, and even today poses a major challenge for the rail transport professionals. We should also note the improvements in the passenger transport in the early 1930's. In order to boost the domestic tourism the so-called "penny trains "and "penny express" were introduced. The Hungarian State Railway Company introduced this after the Italian model providing discounts on trains running from the beginning of April to the end of the year (until the end of the good weather), to many important tourist destinations or resorts. There were trains going to Szeged, Esztergom, Eger, Pécs, Székesfehérvár, Sopron, Györ, Miskolc and most importantly to the Lake Balaton. In 1932 these trains were already very popular - occasionally 500-1000 people could travel with one train.

\subsubsection{Road Transport on the Two Shores of the Lake Balaton}

Beside the shipping and the rail, we have to mention the road transportation as well. There were commercial roads already in the roman era; those traces are still to be found around Keszthely. In the Middle Ages there were military roads on both sides of the Lake. In the $18^{\text {th }}-19^{\text {th }}$ century the quality of the Hungarian roads were a lot worse than the European roads. The construction and maintenance of the roads were based on the work of the peasants, with the lead of the counties. In 1848 István Széchenyi made the first proposal to build roads and highways in Hungary. According to his plans the roads were rather designed to meet local needs in addition to the railway routes. Between 1850 and 1890 institutions were established to deal with the road network, there was 890 miles "public road", where road masters and road scrapers carried out their works. Between 1890 and 1920 the macadam covered pavement was well spread. Cars appeared on the roads in the middle of the 1890's; originally just as sports equipment, but later on they took over important tasks, such as postal service and passenger transport. The period from 1920 until the outbreak of the II WW was characterized by the spared of the motor vehicles and the increase of the road traffic as well. This led to the competition between the road and rail transportation, and number the passenger carrier cars started to increase. Thus the dust-free asphalt and concrete paved roads began to replace the macadam pavements, as it suited the cars better. In 1910 there were 937 passenger cars and 110 vans in Hungary, by the end of the 1920's this number increased to 13394 and 4493 respectively. Besides there were 679 buses and more than 11000 motorcycles on the roads (SCHUCHMANN G. - KISGYÖRGY L. 2001). In the late 1920's there were asphalt roads that led to the waterfront settlements on both sides of the Lake Balaton, on which the tourists could safely ride a bicycle, a motorcycle or drive a car.

Last but not least we have to note that aviation started to infiltrate into the fast approach of the Lake. Siófok-Kiliti town became the target area where the first airport of the Lake Balaton was opened in 1933. Beside the engine airplanes, hydroplanes could also land on the Balaton next to a few towns.

\subsection{The Formation and Development of Hospitality around the Lake Balaton}

It is worth to divide the history of the hospitality around the Lake Balaton to two periods: from the mid- $18^{\text {th }}$ century (when we have the first written records) to the Second World War, and from the end of the Second World War until nowadays. In this study the first part of the history will be processed - divided into three sections. The first section is from mid- $18^{\text {th }}$ century to the end of the Freedom War in 1848-49; the second part is from the Bach Era to the end of the First World War, and the third part is from the Treaty of Trianon to the Second World War.

\subsubsection{From the Mid-18 ${ }^{\text {th }}$ Century to $1848-49$}

The history of lodging that can be supported by written memories begins in the $18^{\text {th }}$ century. Interestingly, we can only find information about settlements on the northern shore of the Lake Balaton, although there could have been inns with one or two beds to accommodate persons on the road on the southern side as well. In Balatonfüred there was an inn near to the sour water sources since 1748. From the hospitality point of view, the Horváth-house has to be mentioned, which was built between 1795 and 1798. The house was built in a very nice and clean Louis XIV-style, there is no larger in this panache throughout the Balaton region. After it was converted into a Hotel, it had 105 bedrooms, and all the important persons of the Hungarian reform Era were guests here. In 1825, the first Anna-ball was held in here. Besides this house, the 12 bedrooms of the newly built Bath-house, the 16 rooms of the inn and 20 rooms of the upper restaurant (which was finished in 1847) provided accommodation for guests and patients.

At the end of the $18^{\text {th }}$ century, in 1799 there are writings about an inn in Keszthely, in 1804 they mention a great guesthouse as well, and that had some guest rooms on the ground floor and also 4 rooms on the upper levels.

As shown on the first figure, in a settlement called Hévíz near Keszthely, which already had the hot water source, in 1786 a castle-like one-storey inn was mentioned; and in 1804 a six-bedroom guesthouse's hiring was announced. (BALLAI K. 1943) 
In Világos the Gamasza-inn was known, where there were a couple of guestrooms for the visitors. (SÁGI J. 1902).

On the basis of the written records, these were the only inns and guesthouses providing accommodation around the Lake Balaton.

\subsubsection{From the Bach Era to the End of the WW1}

Endre Liber writes the followings about the Reform Era - at the beginning of the 1930's -: "The second half of the $19^{\text {th }}$ century until the World War can be considered as the "Age of Civil Journeys". The stagecoach tariffs were becoming cheaper and cheaper, and the rail made travelling more democratized. The development of the European cities inspired the need of resting and free air in the urban population. Urban citizenship also started to change: people gladly travelled to spend their free time in an environment, where they can release themselves from the everyday problems... However, the holidays, sea baths, hiking and winter sports were not even remotely in fashion in the second half of the $19^{\text {th }}$ century as nowadays. The spa-culture is still confined to a very narrow circle in the middle of the century. ... At this time the Lake Balaton started to be noticed, but around 1880 there was only one place people visited: Balatonfüred ... where life was vibrant and stylish.” (LIBER E. 1934 III. volume pp. 234-236)

Based on the above it is perhaps understandable that Hugó Ilosvai does not even mention the Lake Balaton and the towns around the Lake in his book, which was published for the Millennium. BOLEMANN (1900) and SÁGI (1902) however already took the resorts and the Lake into account, reporting about the existing and operating guesthouses and inns, constructions of holiday homes which started at the end of the $19^{\text {th }}$ century; recognizing the role and the future opportunities of tourism. The aim of the forming Bath Societies was to design and develop the bath life of the towns and villages. In many places dozens of resort hotels were built up from scratch in a few years, such as in Siófok or Balatonföldvár. Due to these developments the spa and health resorts proliferated like mushrooms, and so the settlements became known as tourism destinations.

Let us first have a look at the hotels on the northern coast.

The construction of the railways gave impetus to the development of hotels on the northern shore of the Lake Balaton, although only from the middle of the first decade of the twentieth century. Until the rail was not built, Balatonfüred was only accessible from the south side from Siófok, or from the western end of the Lake, from Keszthely. In 1911 besides the Horváth-house more and more hotels were offering accommodation for travellers; therefore in the Eszterházy, the Grand Hotel, the Erzsébet-, Klotild- and Ipoly-courtyards and the Mangold House offered altogether 850 rooms. (Sági, 1902; Magyar Szent Korona, 1911) In 1914 we can find more new hotel names: Gyógyszanatórium, the Stefánia-yard, Teréz-yard, Döry-villa and Annuska holiday home. Balatonfüred is the best-selling and most visited spa resort of the Balaton; the most decorative bath house can be found here. (MÁTRAI R., 1914)

There is a small guesthouse also in Balatonarács, a small town close to Füred, the Patócs inn, where four rooms with six beds await the visitors. (FEKETE G. 1941)

The other big spa resort on the northern shore is Balatonalmádi, where 300 villas and two hotels, the Zsákszálló and the Balaton Hotel, one apartment house and air tents await the visitors, and the patients of the Kneipp hall. (SÁGI, 1902; Magyar Szent Korona, 1911)

At the end of the $19^{\text {th }}$ century the domestic tourism started to boom. The beautiful scenery of the Balaton Highlands, especially the Badacsony hills, and its tourist routes await the tourists, and a couple of guesthouses have also been built, such as the Rodostó Guesthouse, which was built by the Hungarian Tourism Association, and the Szent György Hegy hospice, which was built by the Hungarian Carpathian Association (Balaton, 1942)

On the western part of the Balaton, a city that was accessible by rail since the 1880's, Keszthely gave home to a lot of hotels. Beside the Hullám, the Balaton, the Korona, the Amazon, the Hungária and the Bronner- Hotel, the guests could also find private accommodation. (BOLEMANN I. 1900; SÁGI J. 1902; MÁTRAI R. 1914). Due to tourism, by the turn of the century the lake shore was built in, the new steam boat port was opened in 1891, and the Balaton Museum was funded in 1898 .

All these facilities have been realized for touristic purposes. (Note 1) Around this time the town called Hévíz of Keszthely, that was famous for its thermal lake, went through lots of developments. Based on the thermal water of the lake, in 1907 the Hévíz Sanatorium and Thermal Hotel was built. By 1911, besides the Thermal Hotel, ten other hotel with almost 300 bedrooms awaited the guests; among others the Deák Ferenc House, the Seventh House, the Ferencz József House, the Fourth and Fifth Houses, the Second House, the Rákózi House, the György House, the 
Csányi László House and the Kisfaludy House. Interestingly, this latter one was only accessible for the members of the National Labourer's Insurence Fund. (Magyar Szent Korona, 1911)

Going from Keszthely towards Füred, in Badacsony the Hableány Hotel has 14, the Neptun Hotel has 18 bedrooms that can accommodate guests and these hotels also provide breakfast, lunch, afternoon tea, and dinner and spa entrance. In Révfülöp the Balaton gyöngye has eight, the Rianás has two and the Vihar Hotel has three bedrooms (BOLEMANN I. 1900; SÁGI J. 1902)

The southern shore of the Lake had railway since the early 1860's, which helped the development of the settlements. The first town Balatonvilágos, as a holiday resort was mentioned with a small inn, where there were 5 bedrooms, and the second small town, Balatonaliga also had two hotels at the end of the 1910's. The Rákóczi and the Terézia Hotels have altogether 42 bedroom with 74 beds. (MÁTRAI R. 1914)

The real success story of the southern shore is Siófok, Siófok-Spa. The town used to be an interchange towards Balatonfüred, but most of the visitors realized, that they can enjoy the opportunities given by the Balaton, and also can have the beautiful scenery of the northern shore! The year of the "Revolution" was 1891. In this year the Balaton Spa Company purchased the shore of the Lake, wiped the reed out, filled the frog marshes, and built large hotels directly on the beach. They have planted thousands and thousands of trees, bushes, flowers on the approximately 60 acres land, and built a gorgeous bath house in the lake. From then on, Sioffok is one of the most popular resorts. (MÁTRAI R. 1914) However, the town and the resort are still mentioned separately. Hotels are operating in both parts, on the spa side the Hullám Hotel with 45 rooms, the Központi Hotel with 50, the Sió Hotel with 45; in the town the Balaton, the Mauer, the Mignon, the Fogas and the Gizella-yard. The rooms in the hotels of the resort side have electricity, plumbing and toilet. (BOLEMANN I. 1900; SÁGI J. 1902)

In Szántód, the inn next to the ferry has 3-4 bedrooms. (BOLEMANN I. 1900)

Balatonföldvár has 42 holiday homes, the Kupavezér, the Bendeguz and the Zrínyi Hotels, which have altogether 95 bedrooms, got a thermal spa title in 1905, and became one of the most popular resorts. A contemporary leaflet writes the followings: ,one of the most modern and most elegant resorts of the Balaton. The town has a beautiful park and a great promenade. From Földvár we can see almost the whole Lake Balaton. Just before we can see Tihany, on the left the wonderful and romantic Zala hills, on the right the friendly villas of the Veszprém County on the north shore. The water of its artesian wells has healing power. Sailboats, engine boats and normal boats are available for the visitors. ”(BOlEMANN I. 1900; SÁGI J. 1902; MátRai R. 1914, p. 23)

In Lelle, the Hattyú Hotel with ten bedrooms was converted from a maid's apartment by Imre Szalay at the end of the 1890's, with a restaurant built from brick. In 1905 the Balaton Hotel was build by Dr Milassin. (BOLEMANN I. 1900; SÁGI J. 1902; HORVÁTH J. 1943)

Balatonboglár also has some hotels at the beginning of the $20^{\text {th }}$ century; the Vasúti Hotel, the Balaton Hotel and the Központi Hotel were awaiting the visitors of the season. (MÁTRAI R. 1914)

In Fonyód, there was a 20 roomed inn at the end of the village at the end of the $19^{\text {th }}$ century. In Balaton-berény the guesthouse, the Magyar Tenger has a few bedrooms as accommodation. (BOLEMANN I. 1900; SÁGI J. 1902)

The last in the line of the Balaton shore towns is Balatonszentgyörgy, which was a transit towards Keszthely. The Vasúti Hotel next to the railway station had 7 rooms with 9 beds for the visitors (FEKETE G. 1941)

Already in this period there was a significant number of bedrooms, flats, holiday homes available for the visitors and tourist around the Lake Balaton, all of these could be rented furnished or unfurnished for a couple of days, or even for the whole season. On the northern side Meszes-Györök (the latest Balaton Györök) has 40-50 flats for rent, Szepezd with approximately 30 bedrooms for rent, Alsó Örs with 20 villas, Almádi with 160 rooms in private houses, Kenese had 150 bedrooms. On the south coast Zamárdi had 35 bedrooms, Szárszó 50-60 rooms, Bélatelep 24 villas, Balaton-Keresztúr 800 houses and Hévíz 90 bedrooms were offered for those looking for accommodation. (BOLEMANN I. 1900; SÁGI J. 1902)

\subsubsection{From Trianon to the Second World War}

At the beginning of this period tourism was declining - the main cause of this decline was the end of the First World War, the Aster Revolution in 1918, the dictatorship and retaliation in 1919 and the Treaty of Peace in Trianon. After the great depression between 1929-1932, thanks to the activity the gradually strengthening Horthy-government, growing interest appeared towards the Lake Balaton. The hotel market expanded and more and more settlements became known as resorts around the Lake.

Balatonfüred retained its leading role on the northern shore of the Balaton. After continues development and growth, in the 1940's the following hotels were expecting visitors and tourists: the Astoria with 22 rooms, the Fogas inn with 
4 rooms, the Grand Hotel with 115 bedrooms, the Ipoly Hotel with 51 rooms, the Pannónnia Hotel with 12 , the Stefánia Hotel with 112 bedrooms, the 42 roomed Terézia Courtyard Hotel and the Vasúti Hotel with 7 rooms. (FEKETE G. 1941). In a 1941 brochure Balatonfüred is mentioned as "Szívbajosok Mekkája" (Mecca for those with Heart-disease) (Balaton, 1942)

Tihany, on the Tihany-penninsula also offered a diversity of accommodation to its visitors. A scout camp can be found here, next to the port there is the Sport Hotel that has 14 bedrooms with 20 beds, which used to be one of the most stunning buildings of the Resort with a shady park around. An international Sport Fishing Camp has also been created, where fishermen had the opportunity for fishing and accommodation as well. (Balaton, 1942). Tihany had another guesthouse, the Fogas Hotel with two bedrooms. (FEKETE G. 1941)

Balatonalmádi also went through many changes during this period. Its two hotels could not satisfy the growing demand. In the 1920-30's many hotel projects were implemented. By the beginning of the 1940's, the following hotels offered accommodation in the town: the Abbázia Hotel with 80 bedrooms, the Hattyú Hotel with 10, the Hungária Hotel with 22 rooms, the Pannónia Otthon Hotel with its 80 bedrooms, the 14 roomed Pannónia Villa I, and the 23 roomed Pannónia Villa II, the Pannónia Weekend-houses with 30 bedrooms, the 11 roomed Park Hotel and the Zsák Hotel with 30 rooms. Balatonalmádi was called the "Magyar Abbázia" (Hungarian Abbazia) in 1942. (Balaton, 1942)

Beside the hospices, a hotel appeared on the market in Badacsony, the Hableány-Neptun Hotel with 18 bedrooms. There were two Hotels in a nearby town, Badacsony-tomaj at the beginning of the 1940's: the Himfy Hotel with 10 bedrooms, and the Deutsch Hotel with 6. (Balaton, 1942)

The boom also reached the town of Keszthely that has significant hotel capacity by the beginning of 1940 's. The 60 roomed Balaton and Hullám Hotels, the Bocskay Inn with 12 bedrooms, the inn of E Dolezsár with 2 bedrooms, the 15 roomed Hungária Hotel, the Vasúti Hotel with 9, the Pannónia Hotel with 10 bedrooms and the Amazon Hotel can accommodate the visitors. (FEKETE G. 1941)

Due to the magical effect of its healing water, Hévíz became known internationally as well. In the 1930's there were 7 Hotels and 11 inns, with 40 villas, and in 1936 there were altoghether 700 bedrooms that could accommodate visitors. This capacity significantly grew by the 1940’s. In 1941 the following hotels were listed:

\begin{tabular}{lll}
\hline Name of Hotel & Number of rooms & Number of beds \\
\hline Ferencz József-ház & 28 & 32 \\
\hline Ferenczy Pannónia & 52 & 94 \\
\hline Fölnagy Villák & 24 & n.d. \\
\hline Friedrich Astória & 26 & 42 \\
\hline Friedrich Havay ház & 16 & 30 \\
\hline Friedrich Park & 60 & 100 \\
\hline Friedrich Pálffy villa & 27 & 40 \\
\hline Friedrich Royal & 12 & 20 \\
\hline Györgyház & 32 & 40 \\
\hline Hungária & 33 & 48 \\
\hline Imperiál & 35 & 50 \\
\hline Károly & 27 & 32 \\
\hline Nemzeti & 10 & 18 \\
\hline Pátria & 39 & 58 \\
\hline Pócza villa & 16 & n.d. \\
\hline Rákóczi & 51 & 60 \\
\hline VII. ház & 32 & 38 \\
\hline IV. ház & 4 & 4 \\
\hline Ella villa & 29 & 34 \\
\hline Deák Ferenc-ház & 18 & 20 \\
\hline Csányi-ház & 21 & 40 \\
\hline & 12 & \\
\hline & 32 & 29 \\
\hline
\end{tabular}

Figure 2. Hotels in Hévíz in 1941

Source: Fekete G. Hotel guide of Hungary 1941 
The Pannónia Hotel and restaurant operated in Hévízszentandrás, a town very close to Hévíz.

Let us have a look at the beginning of the northern shore, in Balatonkenese, where the Resort Hotel for the officials of the capital was opened in the mid-1920's, that had 174 bedrooms and can accommodate 274 people at the same time. (Városok Lapja XXII. évfolyam 15-16. szám).

Thereafter let us have a look at the development of the settlements on the southern shore.

In Balatonszabadi a Children Sanatorium is in operation besides the villas, where the children in need can enjoy the pleasant healing air and water of the Lake Balaton. (Balaton, 1942).

The hotel capacity of Siófok also continuously expanded between the two World Wars, in accordance with the demand. At the beginning of the 1940's there were the following hotels and beds in Siófok: Balaton Hotel with 80 bedrooms, Fogas Hotel with 24 rooms and 46 bed, Hableány Inn with 12 rooms and 24 beds, Hobzor Inn with 10 rooms and 91 beds, Központi and Napsugár Hotels with 61 bedrooms and 89 beds, Pannónia Hotel 22 bedrooms 40 beds, Sió and Hullám Hotels 88 rooms 160 beds, Siófok Hotel 16 bedrooms 24 beds, Siklós Hotel 38 rooms 50 beds, Strand Hotel 40 rooms 80 beds, Tünde Hotel 26 rooms 38 beds (FEKETE G. 1941). In Siófok, that was called the "Hungarian Lido", there was a sport airport, hydroplane station and casino as well. (Balaton, 1942)

There were lots of lodging facilities in (Balaton) Zamárdi. Besides the private houses there were 2 hotels, the Balaton Hotel and Bazsó Guesthouse offered comfortable accommodation for the guests (CSAPÓ K., RÉDEY J., STRAUB D.), and the 60 bedroomed MAVOSZ (Association of Hungarian Hunters) Hotel as well. (FEKETE G. 1941)

In Szántód the Vasutas resort offered recreation facilities for the workers of the Hungarian Railway company. (Balaton, 1942)

Balatonföldvár developed year by year after Trianon, and became a preferred resort on the south shore of the Lake Balaton. Besides the coastal and in-town villas of industrialists, actors and merchants, hotels were offering accommodation for the visitors. By the 1940's the following hotels were registered: the Bendegúz Hotel with 20 rooms, the Garabonciás Hotel with 31 rooms, the Kupavezér with 70, the Sellö with 60 rooms (Officers resort), the Zrínyi Hotel with 21 rooms and the 32 roomed Sport Hotel. To complete the recreation, bathing and water sports, there was a golf-course and casino in Balatonföldvár. (Balaton, 1942)

There was busy life in Balatonlelle as well - this town had two hotels before the First World War. (MÁTRAI R. 1914) The resort of the Child Protection League operated here, and by the end of the 1930's visitors could choose from 750 hotel and guesthouse rooms.

The following table shows the guesthouses operating in the town:

\begin{tabular}{llcc}
\hline Name of Guesthouse & Name of owner or tenant & $\begin{array}{c}\text { Number of } \\
\text { rooms }\end{array}$ & Year of built \\
\hline Gyárfás & Oláh Gyárfás Mihály & 52 & 1913 \\
\hline Mária & Orsz. Kat. Tisztviselönők & 42 & 1926 \\
\hline Hungária & Virág István & 35 & 14 \\
\hline Bagolyvár & Bastius Vali & 17 & 1905 \\
\hline Szepesy & Boncz Sándor & 17 & 1933 \\
\hline Pannonia & Boronkay Károly & 22 & 1937 \\
\hline Éden & Frank Dezsó & 18 & 1898 \\
\hline Riviera & Géger Sándor & 9 & \\
\hline Gergely & Gergely István & 32 & \\
\hline Fogas & Walder Imre & 36 & \\
\hline Ruff & Ruff János & 34 & 1928 \\
\hline volt Fabinyi & Breuer Jakab & 20 & 1926 \\
\hline Vass & Vass Vilmos & 21 & 1906 \\
\hline Sirály & Meleg Dezsőné & 36 & \\
\hline Családi & Késmárky Béláné & 16 & \\
\hline Hullám & Válint Károly & 32 & \\
\hline Park & Szalay A.-né & & \\
\hline Trombitás & Guttenberger Antal & & \\
\hline
\end{tabular}




\begin{tabular}{llcc}
\hline Pötty & Schmolen Ferencné & 5 & 1932 \\
\hline Magyar tenger & Schmieder József & 27 & 1926 \\
\hline Otthon & Papp László & 3 & 1937 \\
\hline Ürögdy & Ürögdy István & 10 & \\
\hline Elit & Kántor Imre & 15 & \\
\hline Bristol & Jakab Rózsa & 24 & \\
\hline Fészek & Langhammer & 12 & 1929 \\
\hline Mátyás & Özv. Mátyás Gáspárné & 8 & \\
\hline Zámory & Zámory Ferenc & 15 & \\
\hline Astoria & Holan Ilona & 16 & \\
\hline
\end{tabular}

Figure 3. List of the guesthouses at Balatonlelle at the end of the 1930'

Source: HORVÁTH J. History of Balatonlelle 1943

The resort of the Private Personnel Insurances Institute, opened in 1942, named after Count Pál Teleky, was the last of in line of these constructions until the end of the Second World War. (GOTHARD Zs., JANKÓ GY., 1943).

The interest towards Balatonbolgár resulted in many new buildings in the town. At the beginning of the 1940's, the Balaton Hotel with 16 bedrooms, the Nemzeti Hotel with 41 bedrooms and the 32 roomed Savoy Hotel offered accommodation for the tourists. (FEKETE G. 1941).

Fonyód, Fonyód-Bélatelep and Fonyód-Sándortelep could also accommodate thousands of visitors in different kinds of lodging facilities: hotels, villas, private houses, all of the developed continuously from the 1920's. The Vasúti Hotel, Sirály Hotel, Hullám Hotel and Szarvas Hotel were operating in Fonyód, the Sirály in Bélatelep (MÁTRAI R. 1914) and the Drechsler Hotel in Sándortelep. (FEKETE G. 1941)

The following reflects perfectly the intensity of the development of these years: while in 1934, officially there were 269 Hotels and guesthouses with altogether 5659 bedrooms around the Lake Balaton, 3462 had running water washbasin as well, by 1938 there were officially 474 Hotels, resorts and guesthouses with 7997 bedrooms; namely $57.7 \%$ of the hotels of the country concentrated beside the Lake. Additionally, 15000 villas with 22123 bedrooms awaited the visitors. (Magyar Fürdóélet 1935. 13-14. edition; Magyar Szállodás és Vendéglös 1938. 15. edition) This reflects a $70 \%$ increase in accommodation, and more than $40 \%$ increase in bedrooms in only three years!

The few settlements that could accommodate visitors in the 1740 are expanded many times in the past 200 years. The hotel market of the Lake Balaton made more than half of the whole country's. In 1942, according to the Hungarian Royal Administrative Committee of the Lake Balaton, the following towns are noted as health-, resort-, recreationaland excursion-places around the Lake Balaton:

On the South-Shore: Balatonaliga, Balatonvilágos, Balatonszabadi, Siófok, Balatonújhely, Balatonszéplak, Balatonzamárdi, Szántód, Balatonföldvár, Balatonszárszó, Balatonöszöd, Balatonszemes, Balatonlelle, Balatonboglár, Jankovich-telep, Fonyódliget, Fonyód- Sándortelep, Fonyód-Bélatelep, Balatonfenyves, Balatonmáriafürdő, Balatonberény.

On the North-Shore: Balatonakarattya, Balatonkenese Fővárosi Üdülőtelep, Balatonkenese, Füzföfürdő, Budatava, Balatonalmádi, Káptalanfürdő, Alsóőrs, Csopak-Balatonkövesd, Balatonarács, Balatonfüred, Tihany, Aszófö, Örvényes, Balatonudvari, Antaltelep, Akali, Viriusz-telep, Szepezd, Révfülöp, Rendes, Ábrahámhegy, Kisőrsi szőlőhegy, Badacsonytomaj, Badacsony, Badacsonylábdihegy, Szigliget, Balatonederics, Balatongyörök, Vonyarcvashegy, Gyenesdiás, Keszthely, Hévíz (Balaton, 1942)

These accommodations were to be found in the above settlements according to the 1941 Hotel registry:

\begin{tabular}{|c|c|c|c|c|c|c|}
\hline Settlement & $\begin{array}{l}\text { Number } \\
\text { Hotels }\end{array}$ & of & $\begin{array}{l}\text { Number } \\
\text { rooms }\end{array}$ & $\begin{array}{l}\text { Number of } \\
\text { beds }\end{array}$ & $\begin{array}{l}\text { Number } \\
\text { bathrooms }\end{array}$ & of \\
\hline \multicolumn{7}{|c|}{ South-Shore } \\
\hline Balatonaliga & & 1 & 42 & 74 & & - \\
\hline Siófok & & 11 & 417 & 570 & & 36 \\
\hline $\begin{array}{l}\text { Balaton-Zamárdi } \\
\text { Szántód }\end{array}$ & & 1 & 60 & 100 & & 4 \\
\hline
\end{tabular}




\begin{tabular}{lrrrr}
\hline Balatonföldvár & 6 & 234 & 360 & 26 \\
\hline Balatonlelle & 1 & 102 & 145 & 4 \\
\hline Balatonboglár & 3 & 89 & 139 & 6 \\
\hline Fonyód-Sándortelep & 1 & 20 & 33 & - \\
\hline Fonyód-Bélatelep & 1 & 23 & 57 & 2 \\
\hline Balatonszentgyörgy & 1 & 7 & 9 & - \\
\hline \multicolumn{1}{c}{ in the aggregate } & 26 & 994 & 1487 & 78 \\
\hline \multicolumn{1}{c}{ North-Shore } & & & 23 \\
\hline Balatonkenese & 1 & 174 & 274 & 27 \\
\hline Balatonalmádi & 9 & 290 & 491 & - \\
\hline Balatonarács & 1 & 4 & 6 & 9 \\
\hline Balatonfüred & 8 & 365 & 485 & 2 \\
\hline Tihany & 2 & 16 & 24 & 1 \\
\hline Badacsony-Tomaj & 2 & 16 & 25 & - \\
\hline Badacsony & 1 & 18 & 28 & 4 \\
\hline Keszthely* & 8 & 108 & 164 & 25 \\
\hline Hévíz & 21 & 592 & 800 & 91 \\
\hline \multicolumn{1}{c}{ in the aggregate } & 53 & 1583 & 2297 & $\mathbf{1 6 9}$ \\
\hline Balaton together & $\mathbf{7 9}$ & $\mathbf{2 5 7 7}$ & $\mathbf{3 7 8 4}$ & \\
\hline
\end{tabular}

* no data has given at Amazon hotel

Figure 4. List of the Hotels at the Lake Balaton in 1941

Source: FEKETE G. Hotelguide of Hungary 1941.

\section{Summary}

The history of the lodgings of the Lake Balaton can be followed with written relics from the mid- $18^{\text {th }}$ century. Its first two hundred years were slower in development, but by the 1930's the development became really fast. The geographic facilities, natural scenery and phenomena are great tourism attractions. The water of the Lake, the differences between the two shores, the changing of the seasons, the healing and hot water springs, the climate and the sunshine attracts visitors.

The development of the different transportation methods helped greatly the development of tourism and hospitality industry. After the appearance of the steam machines, revolutionary changes occurred: steam ships replaced the sailing ships, steam trains and vehicles - passenger and freight vehicles as well -, and at the beginning of the $20^{\text {th }}$ century planes appeared. These made the approaching of the lake easier and quicker. At first on the south-shore, and 40 years later railway transport operated on the north shore - visitors could reach the Balaton within only a few hours. The water transportation also accelerated when the steam ships and engine boats appeared. By the 1930 planes and hydroplanes appeared above the Lake Balaton.

The history of lodging can be divided into three parts from the end of 1740's to the Second World War. The first period ended with the 1848-49 Freedom War, and it can be characterized with a few inns, few bedrooms and few place. The most known and most visited place was Balatonfüred in this era.

The period between the Bach-era and Trianon can be characterized with slow development; the around the Millennium the development became quicker, after the construction of the railway on both sides of the Lake.

Besides Balatonfüred, Keszthely and Hévíz were the leading towns of the northern shore; while on the south-side Siófok developed the most. Despite the slow development, the capacity of Hotels and number of resorts multiplied by the 1910's.

The third era started with heavy political burdens, after Trianon the size of the country was significantly reduced. Accordingly, the interest and developments slowed down for a few years. But then more and more intense interest began towards the Lake, more and more people visited the Lake, which resulted in new developments. Besides the hotels and guesthouses, tourist house and hospices appeared air tents, private houses, resorts, sanatoriums, sport fishing camps and youth camps could accommodate the visitors. In several villages there were resorts operated by insurance companies, accommodations only reserved for members of the different companies. Most of the towns now offered other facilities beside accommodation and meals, for example golf, water sport, tennis and casino. In the 
1930's MÁV (Hungarian Railway Company) started the so-called penny-trains that assisted domestic tourism. In the mid-1930's during three short years the capacity of bedrooms expanded by more than $70 \%$, the capacity of beds grew by more than $40 \%$, but it was still not enough to meet the growing number of visitors.

The last couple years of this period was affected deeply by the happenings of the Second World War - the likes and interest in travelling declined, people did not have money and the possibility to travel, therefore tourism almost completely stopped.

The boom only started years after the ending of the Second World War, but those years are already a chapter of another study...

\section{References}

(1907). évi XX. törvénycikk a balaton-vidéki vasut megépitéséröl

A Magyar Szent Korona országainak Gyógyfürdöi és Gyógyforrásai Prospektus gyüjtemény Országos Balneológiai Egyesület 1911 Budapest 9. oldal

Balaton 1942 A m. kir. Balatoni Intéző Bizottság kiadása M. kir. Honvéd Térképészeti Intézet

Balaton Kiemelt Üdülökörzet Hosszú Távú Területfejlesztési Koncepció 2020-ig Balatoni Integrációs Közhasznú Nonprofit Kft. 2009. 48-49. Oldal

Bolemann, I. (1900). A balatonparti fürdők és üdülőhelyek leirása. Budapest, Kilián p. 55.

Cholnoky, J. (1929). Magyarország Földrajza. Franklin-Társulat reprint kiadás Kráter Pomáz 2010.

Cholnoky, J. (1929). Magyarország Földrajza. Tudományos Gyüjtemény 101 Danubia Könyvkiadó Dunántúl Egyetem Nyomdája Pécs.

Fazekas, M. (2005). Az Észak-balatoni vasút története, 1909-1999. Balatonfüred Városért Közalapítvány Balatonfüred.

Fekete, G. (összeállította) (1941). Magyarország Szállodáinak Névjegyzéke. Globus, Budapest.

Gothard, Z.S., Janko, G.Y (1943). Üdülök és sportszállók tervezése - épitése. Mérnöki Továbbképző Intézet Királyi Magyar Egyetemi Nyomda Budapest.

Gyorstájékoztató, KSH. (2014). Kereskedelmi szálláshelyek forgalma 2014. 12. 8. sorszám: 158.

Horvath, J. (1943). Balatonlelle története. Egyházmegyei Könyvnyomda, Veszprém 171. Oldal.

Idegenforgalmi értekezlet Balatonfüreden, in Városok Lapja XXII. Évfolyam 15. és 16. szám. 1927. július 1. Budapest 153. Oldal.

Katalin, C., Judit, R., \& Dezso, S. Sztárvendég Bookmarket Kft. Innova-Print Kft. 95. Oldal.

Matrai, R. (1914). II. Balaton. in Kárpátoktól-Adriáig Kirándulási Útmutatók. Magyar Földrajzi Intézet Részvénytársaság Budapest 29-30. Oldal.

Padanyi, G.J (1935). Idegenforgalom és épitészet. különnyomat A Magyar Mérnök- és Építész-Egylet Közlönye 1935. december 15-i, 51-52. számából Stádium Sajtóvállalat Rt. Budapes.

Retrieved July 31, 2011, from http://www.hajokanno.hu/tortenelem.html

Retrieved July 31, 2011, from http://www.tihany.hu/hu_muemlekek.htmhttp://www.tihany.hu/hu_muemlekek.htm

Retrieved July 31, 2011, from http://www.zalaszam.hu/utikonyv/keszth.htm

Sagi, J. (1902). A Balaton irásban és képben. A Magyar Tengernek és vidékének leírása a Balatoni Fürdö- és nyaralóhelyek elfogulatlan és kimerítő ismertetése Keszthely, A „Keszthelyi Hírlap” kiadása p. 346.

Schuchmann, G., \& Kisgyorgy, L. (2001). Közlekedésszervezés - utak. Mủegyetemi Kiadó Budapest

\section{Note}

Note 1. http://www.zalaszam.hu/utikonyv/keszth.htm 